\title{
Pasteurella septica infection in respiratory disease
}

\author{
R. H. E L L IS \\ From the Gloucestershire Royal Hospital
}

Bacteria of the genus Pasteurella are well recognized in the veterinary world as the cause of various diseases of domestic, farm, and wild animals, such as fowl cholera and epidemic haemorrhagic septicaemia of swine and cattle. Since the earliest reports of human infection from Europe, Schipper (1947) collected 21 cases recorded between 1919 and 1946: eight of these had infected bites, and seven had pulmonary infection. Of the 37 cases reviewed by Olsen and Needham (1952) and seen at the Mayo Clinic, 35 had disease of the upper and lower respiratory tract, and bronchiectasis was confirmed by bronchography in 30. Pasteurella septica was recovered from bronchial aspirates but rarely from sputum, and it was considered that the organism was a secondary invader in pre-established bronchiectasis. In the United Kingdom, Cawson and Talbot (1955) reported two cases of bronchiectasis in farmers secondarily infected with $P$. septica and suggested cats and dogs as the commonest source-an observation supported by Smith (1955), who isolated it from tonsillar swabs in $54 \%$ of 111 London dogs. Further case reports by Bartley (1960), DeBoer and Dumler (1963), Freigang and Elliott (1963), Brodie and Henderson (1963), and Maneche and Toll (1964) confirm that $P$. septica may appear in the sputum cultures of patients with chronic infection of the respiratory tract following animal contact.

Because it is an unusual finding, and in view of the recent interest shown in zoonoses generally, eight cases encountered in Gloucestershire during a four-year period are reported; in some of them the infection may have played an important part in the current acute respiratory illness.

\section{ILLUSTRATIVE CASE HISTORIES}

CASE 7 A housewife, aged 50, who had suffered from periodic bronchitis for five years, was admitted to hospital with widespread bronchopneumonia in 1965 , and $P$. septica was the sole organism in the sputum culture. It was resistant to sulphonamide, penicillin, tetracycline, and erythromycin, but clinically and radiologically she responded to ampicillin, and $P$. septica disappeared from the sputum. Subsequent bronchography revealed generalized bronchial diverticulosis. During further chest infections six, eight, and nine months later, $P$. septica reappeared in the sputum cultures, and her serum agglutinated a viable suspension of her sputum organisms, on each occasion at a maximum titre of $1 / 80$. She had a cat.

CASE 8 A housewife of 75 was admitted to hospital with bilateral lower lobe pneumonia, and both Staphylococcus aureus and P. septica were cultured from the sputum in equal proportions. She improved generally and radiologically after treatment with novobiocin, and Staph. aurcus disappeared from the sputum, but $P$. septica persisted in two further cultures during the following three weeks, when she relapsed with pneumonia, developed right-sided empyema, and died. Necropsy showed extensive bronchopneumonia, lower lobe bronchiectasis, and a right-sided empyema. In addition, there was cirrhosis of the liver, and microscopical examination revealed small abscesses in which were clumps of small Gramnegative cocco-bacilli with bipolar staining, indistinguishable from $P$. septica. She had been in contact with a cat.

\section{DISCUSSION AND CONCLUSIONS}

All eight patients suffered from chronic disease of the upper or lower respiratory tract, and all gave histories of close contact with dogs, cats. cattle, or sheep.

During acute episodes of infection, $P$. septica was isolated on more than one occasion from the sputum of all cases except case 1, and it was notably resistant to erythromycin in five of the eight cases. In all instances except the first isolation in case 8 , the second in case 4 , and the fourth in case 6 , it was the predominant organism, and although it occasionally persisted after antibiotic therapy without harmful effect, as in case 3, its removal from the sputum was always associated with clinical improvement.

Although sputum culture in patients with chronic pulmonary disease is often thought to be unhelpful, this series suggests the opposite. In two patients who died from pneumonia while still 
T A B L E

FEATURES IN 8 CASES

\begin{tabular}{|c|c|c|c|c|c|c|c|}
\hline Case & Age & Sex & $\begin{array}{l}\text { Animal } \\
\text { Contact }\end{array}$ & Respiratory Disease & $\begin{array}{l}\text { Pasteurella } \\
\text { Isolations }\end{array}$ & Antibiotic Resistance & Other Features \\
\hline 1 & 51 & $\mathbf{F}$ & Dog & $\begin{array}{l}\text { Post-tuberculous } \\
\text { bronchiestasis; } \\
\text { recurret }\end{array}$ & 1 & Sulphonamide & $\begin{array}{l}\text { No further isolations } \\
\text { after severing anima } \\
\text { contact }\end{array}$ \\
\hline 2 & 56 & $\mathbf{M}$ & Dog & $\begin{array}{l}\text { Emphysema; broncho- } \\
\text { pneumonia }\end{array}$ & 2 & $\begin{array}{c}\text { Erythromycin, } \\
\text { novobiocin }\end{array}$ & $\begin{array}{l}\text { Death due to } \\
\text { pneumonia }\end{array}$ \\
\hline 3 & 56 & $\mathbf{M}$ & $\begin{array}{l}\text { Cattle, sheep, } \\
\text { dog, cat }\end{array}$ & $\begin{array}{l}\text { Bronchiectasis ; } \\
\text { recurrent bronchitis }\end{array}$ & 7 & None & $\begin{array}{l}\text { Serum agglutinins } \\
\text { absent }\end{array}$ \\
\hline 4 & 73 & $\mathbf{M}$ & $\begin{array}{l}\text { Cattle, pigs, } \\
\text { dog }\end{array}$ & $\begin{array}{l}\text { Chronic sinusitis; } \\
\text { recurrent bronchitis }\end{array}$ & 3 & Erythromycin & \\
\hline 5 & 56 & $\mathbf{M}$ & Cat & $\begin{array}{l}\text { Emphysema; bronchial } \\
\text { diverticulosis; } \\
\text { recurrent bronchitis }\end{array}$ & 2 & $\begin{array}{l}\text { Sulphonamide, } \\
\text { erythromycin }\end{array}$ & $\begin{array}{l}\text { Death due to cor } \\
\text { pulmonale }\end{array}$ \\
\hline 6 & 72 & $\mathbf{M}$ & Dog, cat & $\begin{array}{l}\text { Bullous emphysema; } \\
\text { recurrent bronchitis }\end{array}$ & 4 & Erythromycin & $\begin{array}{l}\text { Death due to } \\
\text { respiratory failure }\end{array}$ \\
\hline 7 & 50 & $\mathbf{F}$ & Cat & $\begin{array}{l}\text { Chronic bronchitis; } \\
\text { bronchial diverticu- } \\
\text { losis; broncho- } \\
\text { pneumonia }\end{array}$ & 7 & $\begin{array}{l}\text { Sulphonamide, } \\
\text { penicillin, tetra- } \\
\text { cycline, erythromycin }\end{array}$ & $\begin{array}{l}\text { Serum agglutinins } \\
\text { present (titre } 1 / 80 \text { ) } \\
\text { during three } \\
\text { infections }\end{array}$ \\
\hline 8 & 75 & $\mathbf{F}$ & Cat & $\begin{array}{l}\text { Bronchiectasis; } \\
\text { bronchopneumonia; } \\
\text { empyema }\end{array}$ & 3 & None & $\begin{array}{l}\text { infections } \\
\text { Death due to } \\
\text { pneumonia and } \\
\text { empyema; } P \text {. septice } \\
\text { present in cirrhotic } \\
\text { liver abscesses at } \\
\text { necropsy }\end{array}$ \\
\hline
\end{tabular}

excreting $P$. septica in large quantities, and in two others with advanced emphysema who died within a year of the last isolation of the organism, I think that it contributed to the fatal outcome. The general improvement after appropriate chemotherapy and the disappearance of the organism suggest that these chance super-infections were having a deleterious effect.

The demonstration of a significant antibody titre would confirm host reaction, but although this has been reported in non-respiratory infections, such as puerperal septicaemia by Brugnatelli (1913) and peritonitis by Ludlam (1944) and Coghlan (1958), none has been reported in respiratory disease apart from the cases of empyema and pneumonia described by Ortscheit (1921) and Foerster (1938) respectively. The difficulty in demonstrating serum agglutinins has been emphasized more recently by Brodie and Henderson (1963). In case 7 of this series, serum agglutinins were found to a maximum titre of 1 in 80 during the last three exacerbations of bronchitis during which $P$. septica was grown alone from the sputum. Although such findings in only one patient are not conclusive of general pathogenicity, they suggest that $P$. septica as an opportunist invader may play an important role in some chest infections following animal contacts in people with already damaged lungs. Presumably bacteria which would normally be thrown to the side by a healthy person can assume greater importance where there is a pre-existing breakdown in the resistance of normal skin or mucosa.
In case 8 the presence of clumps of $P$. septicalike organisms in the cirrhotic liver abscesses at as time when this organism was being excreted ino the sputum suggests that metastatic lesions mayo have been produced by a wider extension of theo organism following further breakdown in host $\overrightarrow{0}$ resistance. Searches for similar groups of bacteria 3 in the lung sections have proved negative.

Frequency of bronchiectasis as a background to $P$. septica infection is confirmed, and this series further demonstrates that other permanent struc-은 tural abnormalities of the respiratory tract mayx underlie it, such as bronchial diverticulosis, bullous? emphysema, and abnormalities of the nasal sinuses. These findings emphasize the facility with which damaged tissue may be contaminated, and justify combined bacteriological and serological investigations for $P$. septica in new exacerbations of infection in chronic chest disease, where there has been close contact with domestic or farm ज animals.

\section{SUMMARY}

$P$. septica was the predominant organism in the sputum of eight cases of chronic respiratory disease with acute exacerbations, four of whom subsequently died. All had a history of recent animal contacts.

The findings of serum agglutinins at a titre of 1 in 80 in one case, and clumps of organisms in abscesses in the liver of another, support the impression that $P$. septica may occasionally play 
a more important pathogenic role than has hitherto been suspected.

I am grateful to my colleagues, Drs. F. J. D. Knights, J. B. W. Hayward, and J. Giles, of the Gloucestershire Royal Hospital, for permission to include their patients in this series ; and to Drs. P. G. Mann, J. E. Mackey, and the staff of the Public Health Laboratory, Bath, and Dr. C. T. Vincent, of the Gloucestershire Royal Hospital, for bacteriological assistance. My thanks are also due to Dr. H. M. Foreman, of Sully Hospital, Cardiff, for advice in the preparation of this paper.

\section{REFERENCES}

Bartley, E. O. (1960). Pasteurella septica in chronic nasal sinusitis. Lancet, 2, 581.

Brodie, J., and Henderson, A. (1963). Pasteurella multocida: human infections. Scot. med. J., 8, 314.

Brugnatelli, E. (1913). Puerperalfieber durch einen Bacillus aus der Gruppe "Hämorrhagische Septikämie" (Pasteurella). Z Zbl. Bakt., 1 Abt. Orig., 70, 337.
Cawson, R. A., and Talbot, J. M. (1955). The occurrence of Pasteurella septica in bronchiectasis. J. clin. Path., 8, 49.

Coghlan, J. D. (1958). Isolation of Pasteurella multocida from human peritoneal pus and a study of its relationship to other strains of the same species. J. Path. Bact., 76, 45.

DeBoer, R. G., and Dumler, M. (1963). Pasteurella multocida infections. Amer. J. clin. Path., 40, 339.

Foerster, W. (1938). Pasteurella-Bakterien als Krankheitserreger beim Menschen. Klin.Wschr., 17, 599.

Freigang, B., and Elliott, G. B. (1963). Pasteurella septica infections in humans. Canad. med. Ass. J., 89, 702.

Ludlam, G. B. (1944). Isolation of Pasteurella septica from an appendicular abscess. J. Path. Bact., 56, 307.

Maneche, H. C., and Toll, H. W. (1964). Pulmonary cavitation and massive hemorrhage caused by Pasteurella multocida. New Engl. J. Med., 271, 491.

Olsen, A. M., and Needham, G. M. (1952). Pasteurella multocida in suppurative diseases of the respiratory tract. Amer. J. med. Sci., 224, 77.

Ortscheit, E. (1921). Un nouveau cas de Pasteurella chez l'homme. C.R. Soc. Biol. (Paris), 84, 941 .

Schipper, G. J. (1947). Unusual pathogenicity of Pasteurella multocida isolated from the throats of common wild rats. Bull. Johns Hopk. Hosp., 81, 333.

Smith, J. E. (1955). Studies on Pasteurella septica. I. The occurrence in the nose and tonsils of dogs. J. comp. Path., 65, 239. 